\title{
Community-Based Forest Management in Indonesia as a Forest Fire Mitigation Strategy in the Threat of Climate Change
}

\author{
Ardiyanto W Nugroho ${ }^{1 *}$ \\ ${ }^{1}$ Natural Resources Conservation Technology Research and Development Center (BP2TKSDA), Ministry of Forestry, \\ Samboja, Kutai Kartanegara, East Kalimantan, 76112, Indonesia \\ *Corresponding author. Email: ardiyanto.nugroho@gmail.com
}

\begin{abstract}
Forest fire in Indonesia is complicated, influenced by social conflicts between the government and local people or forest landholder companies. In an extreme drought resulting from global warming, forest fires result in severe forest degradation, threatening forest biodiversity. This paper will discuss; the potential impacts of forest fires influenced by climate change and social conflicts on tropical forest biodiversity in Indonesia and; Community Based Forest Management (CBFM) as a potential solution to tackle forest fires and conserving forest biodiversity how to respond to the challenges. By applying the study of literature, the results show that social conflict aggravates climate change's impact on forest biodiversity and that climate change increases the risk of forest fires. Meanwhile, the existing policies are ineffective in tackling forest fires. Meanwhile, an adaptation strategy to combat forest fires in Indonesia is reformulating the existing regulations causing forest biophysical changes in tropical forests that can potentially lead to massive forest fires. On the other hand, CBFM is an alternative way of forest fire mitigation and biodiversity protection because it offers greater access to forest resources and preserving them sustainably. However, CBFM needs to be improved by providing field assistants and establishing a special agency or task force. In conclusion, climate change has indirect negative impacts on forest biodiversity in Indonesia, and CBFM is one of the potential mitigation options to tackle forest fires.
\end{abstract}

Keywords: Community Based Forest Management, Forest fires, Climate change, Mitigation

\section{INTRODUCTION}

Indonesia has significant forest areas that play important roles in biodiversity conservation. Forests provide habitats for various species of plants and animals. Indicated by species richness and endemic animals and plants, Indonesia and its surrounding areas in Southeast Asia are regarded as one of the world's highest biodiversity species [1,2]. In addition, according to the Ministry of Forestry Indonesia 2014, forest areas in this country are about 129 million hectares comprising various types of forest such as tropical rain forests, mangroves, peat swamp forests, and deciduous forests across five large islands.

Meanwhile, climate change is one of the potential threats to forest biodiversity in Indonesia. As it influences the drought intensity, climate change increases the vulnerability to forest fires. On the other hand, existing policies in this country are ineffective in combatting forest fires due to the complexity of the cause of forest fires in this country. Although several institutions have been established, forest fires still occur in this country, resulting in significant forest biodiversity impacts. Therefore, policies in combating forest fires need to be improved by including climate change as one of the main considerations to protect forest biodiversity in Indonesia.

The cause of forest fires in Indonesia is complicated. It is related to social conflicts in forestry between the government and local people or forest landholder companies. Local people encroach and burn forest areas to open new agricultural land, while some forest companies use fire for land clearing. In an extreme drought resulting from global warming, forest fires result in severe forest degradation, which in turn has negative impacts on forest biodiversity. 
This essay will discuss the potential impacts of climate change on tropical forest biodiversity in Indonesia. At first, the relationships between climate change, drought, social conflicts, and forest fires in Indonesia are explored. Then, forest fires' impacts on biodiversity are explained, including their implications to forest fire control policies in this country. A third, this essay will also discuss the weaknesses of existing policies in tackling forest fires and how to improve those policies as part of adaptation strategies that need to be done by the government in combating forest fires. In forest fire mitigation strategies, I will argue that Community Based Forest Management (CBFM) is a potential solution to tackle forest fires in Indonesia and conserving forest biodiversity, including how to respond to the challenges.

\subsection{Climate Change, Drought and Forest Fires in Indonesia}

Forests in tropical regions have successfully adapted to probably more severe changing climate over thousands of years ago because of its species richness, allowing them to adapt and survive to the global and environmental changes [3]. However, an increase in anthropogenic greenhouse gases results in abiotic environment changes, influencing tropical regions' plant functions [4]. In addition, [5] predicts that the first response to climate change in Asian forests changes in plant phenology, which also negatively impacts both flora and fauna that rely on regularly available plant responses. Nevertheless, the degree to which tropical plants respond to these changes remains uncertain [4]. This indicates that climate change directly affects the tropical rainforests, but the vegetation's response to the changes is unclear.

However, indirectly, climate change poses serious challenges to forest biodiversity conservation in Indonesia. An increase in greenhouse gas emissions in the atmosphere might result in climate disruptions, potentially increasing the period of drought and the wet season. A prolonged drought period might increase the fire susceptibility of tropical rain forests. A study conducted by [6] shows that a prolonged drought resulting from El Nino/ Southern Oscillation (ENSO) in 1997-1998 has been linked to Indonesia's forest fires. [7] reveal that severe forest fires after a 12-month drought burn 5.2 million ha of forests in the period in East Kalimantan, causing significant loss of forest biodiversity. Furthermore, [8] reveals that both prehistoric and current forest fires in the tropics are influenced by drought, which El Nino caused. When the dry season stimulates trees to shed their leaves, that results in potential flammable fuel on the forest floor, and prolonged drought increases fire risk by decreasing the moisture content [8]. Although El Nino is a natural phenomenon in the Pacific region, it is estimated that climate change increases the El Nino events trend [9]. Thus, climate change has an indirect effect on forest biodiversity by increasing the potential risk of forest fire due to drought.

Furthermore, forest fires in this country are influenced by complex factors, such as the interaction between climate, land cover, and land management, influencing forest fires in Indonesia [10]. Land management, including forest conversion using fire, is strongly related to social conflicts; rural people who want to open new agricultural land by occupying the state's forest land [11] and companies that illegally clear the forest land using fires [12,13]. Compared to mechanical land clearing, burning is considered the cheapest land-clearing method [14]. In an extreme drought due to $\mathrm{El} \mathrm{Nino,} \mathrm{forest} \mathrm{fires,} \mathrm{which} \mathrm{large}$ landholders or local people cause, might have a larger impact on the forest areas than in normal dry season. In addition, there is a strong relationship between repeated forest fires and increasing social conflicts between local people and the government in Sumatra [15]. The conflicts are mainly about land tenure and land use rights. Thus, this country's social conflicts are an influential factor that aggravates climate change's impact on forest biodiversity.

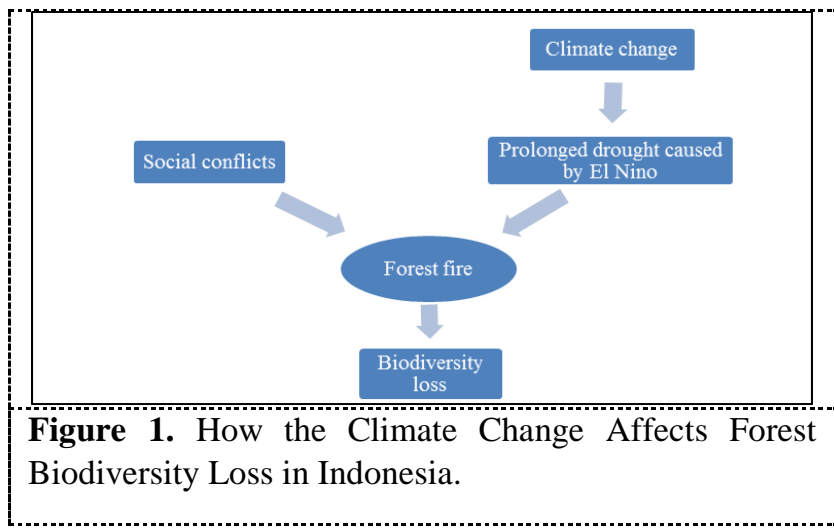

\subsection{Significant Impacts of Forest Fires on Biodiversity}

A forest fire has significant effects on forest biodiversity in Indonesia because it alters the forest composition and structure. Research conducted by [16] reveals that forest fires significantly decrease the number of trees and species in tropical forests, mainly affecting the dominant tree species. For instance, there are 91 to 478 tree species documented in the tropical rain forest in Kalimantan [17], which would be affected by forest fires. In the other tropical forest region, forest fires on the surface result in significant forest degradation in Brazil Amazonian, and the threat of fire increases when prolonged drought occurs [18]. Furthermore, forest fires threaten the endemic habitat for endangered animals such as Nasalis larvatus [19] and Pongo pygmaeus [20]. Thus, forest fires in various degrees are a significant 
disturbance in Indonesia's tropical rain forests, resulting in the loss of endemic animal and plant species.

Forest fires in tropical forests might significantly impact forest regeneration because fire significantly decreases seed availability on the forest floor. An experiment conducted by [21] shows that fire can kill the dormant seeds by $85 \%$ in the little layer and $60 \%$ in the uppermost $1.5 \mathrm{~cm}$ of soil in the forest floor. This might affect forest regeneration; however, there is no significant recovery in the number of plant species after 15 years of burning in East Kalimantan's tropical forest [16]. Furthermore, forest fire also affects the flowering and fruiting intensity of trees in surrounding burned areas [21]. Thus, a forest fire is a significant disturbance to Indonesia's tropical forests because the fire causes tree mortality and inhibits forest regeneration by diminishing seeds in the forest floor.

Forest fires also harm the environment by releasing a significant amount of carbon emission into the atmosphere. The amount of carbon emission as a result of forest fires in Indonesia in 2006 is estimated at $303 \pm$ $118 \mathrm{Tg} \mathrm{C}$ year $^{-1}$, which was occurred after drought influenced by El Nino in that year [22]. The study also reveals that the carbon emission from forest fires in Indonesia is related to climate change. The amount of carbon emission is low at the La Nina period in 2000 (47 $\pm 29 \mathrm{Tg} \mathrm{C}$ year $\left.^{-1}\right)$. In addition, the intensity of drought also influences the forest fire in this country which the carbon emission can indicate. When the strongest El Nino occurred between 1997 and 1998, the total estimated carbon emission from the forest fire in Indonesia was $870 \mathrm{Tg} \mathrm{C}$ [22].

\subsection{Some Ineffectiveness of the Existing Policies in Indonesia to Combat Forest Fires}

Indonesia has a long history of forest fire control policies. In response to significant forest fires in the 1980s, the Indonesian government has enacted several policies to control and prevent the fires. For example, according to [23] the ministry of forestry has released decree No. 188/Kepts-II1995 to create the National Centre for Forest Fire Control (Pusdalkarhutnas/Pusat Pengendalian Kebakaran Hutan Nasional) in 1995 to combat forest fire in forest areas. Meanwhile, there is also decree No. Kep-18/MenLH/3/1995 to set up a National Coordinating Team for Land Fire (TKNKL) in 1996. This decree was issued by the Ministry of Environment, which aimed to combat forest fires located outside forest areas. In addition, a special task force specialized to combat forest fire, namely 'Manggala Agni', has been established under the ministry of forestry [24]. This special task force is responsible for controlling forest fires in state forest areas. Ineffectiveness
However, the policies are ineffective in tackling forest fires [23], which were indicated by the significant forest fires that still occurred in 1997/1998, 2006 [25], and 2015 [26], in which the intensity of the fire is influenced by prolonged drought. This indicates that the adaption and mitigation strategies need to be improved to tackle the problem by including climate change as the main consideration. Several factors influence the ineffectiveness of existing policies and institutions in combating forest fire in Indonesia; forest biophysical changes, lack of involvement of relevant stakeholders in constructing policies, poor communications between institutions responsible for fire control, and incoherence existing policies related to land clearance.

Forest biophysical changes have contributed to the ineffectiveness of forest fire control policies in Indonesia. These changes are mainly caused by human activities such as; poor forest management practices and forest conversion for agricultural purposes [6]. For example, in the one million hectare rice project in 1996 in Central Kalimantan, biophysical changes because of canal construction results in extensive draining of peat swamp forests [27]. As a consequence, the forests become more susceptible to forest fires. In a prolonged drought due to the El Nino, peat swamp forest draining aggravates the widespread forest fires in that region in 1997-1998 [28].

Another factor contributing to forest fire control policies' ineffectiveness in this country is the lack of relevant stakeholders' involvement in the policy formulation. For example, the government does not involve local communities, including their local knowledge and researchers, in formulating the policies. Furthermore, the existing policies only focus on immediately responding to forest fire events without understanding the underlying cause [23], which is social conflicts.

The other factor that causes the ineffectiveness of existing forest fire control policies is the poor communication between institutions responsible for fire disasters. Besides 'Pusdalkarhutnas' and 'TKNKL', an institution is established in response to disaster events, namely National Agency for Disaster Management (BNPB/Badan Nasional Penanggulangan Bencana). However, during forest fire events, the poor communication between these institutions results in ineffective fire control. For instance, the BNPB can only organize the relevant institutions after the event has been declared as a disaster by the government [23]. This means that BNPB cannot control the other institution before the large forest fires are declared a disaster. Thus, a low-scale fire event cannot be tackled as a result of poor communication.

The incoherence of Indonesia's policies also contributes to forest fire control policies' ineffectiveness in this country. Some regulations allow the use of fire 
for land clearance in Indonesia. These regulations are intended to regulate local ethnic people using fire for agricultural purposes, which have been conducted for many years. For example, in the ministerial of environment regulation number 10/2010 [29], it is stated in article 4 that local ethnic communities are allowed to burn forest areas with a maximum of 2 hectares per household for land preparation before planting local plants. In practice, the local leader has to supervise it, and the activity cannot be done in long dry season conditions. Furthermore, in the higher level of regulation, a government regulation number 32/2009 about Environmental Protection and Management allows opening new agricultural land using fire considering local wisdom. These regulations increase forest fires' vulnerability in a prolonged drought because it is hard to calculate the burning time.

\subsection{Several Adaptation Strategies for Addressing Forest Fires}

The first step of adaptation strategies to effectively combat forest fires in Indonesia might be to reformulate the existing regulations, particularly any regulations and policies that cause forest biophysical changes in tropical forests, leading to massive forest fires. For example, the government needs to formulate policies that strictly prohibited the peat swamp forests draining in Kalimantan. Subsequently, the government might need to change the regulations that allow local communities to burn the forest. Although fire for land clearance is prohibited in the dry season, it is hard to ensure that the local communities would not conduct it because of the limited number of government officers monitoring and supervising the large forest areas in this country. Furthermore, in formulating the new policies and regulations, the local communities need to be involved.

On the other hand, the government might need to provide environmental education on sustainable agriculture for local communities to optimize the existing agricultural land without opening new areas. In this country, the government implemented a successful environmental policy when Integrated Pest Management (IPM) program was introduced to decrease pesticide use in rice production in the early 1980s [30]. In this program, the government creates Farmer Field School to train farmers to use natural predators instead of pesticides in combating pests in their rice fields [31].

In addition, the government needs to establish policies that improve communication among institutions responsible for combating forest fires. For example, it is necessary to set a regulation that allows a single institution, such as BNPB, to organize all the institutions related to forest fire events in any conditions without the events are being declared as a disaster by the government. This is important to immediately respond to the small events of forest fires before they become larger.

\subsection{Addressing Social Conflicts and Mitigating Forest Fires with CBFM}

As the owner of forest areas in Indonesia, the state plays an important role in forest fire mitigation in climate change. In terms of combating forest fire, the government needs to consider the social aspect in addressing the problem to reduce forest fire risk. This is because Indonesia's forest fires are mainly caused by humans, large landholders (plantation companies), or small landholders (rural people). As a result, the government needs a different approach to solve the problem. For the large landholders, law enforcement might be an effective way to reduce the risk of forest fires. However, as poverty is one of Indonesia's main problems, law enforcement might not be an effective solution to combat forest fires caused by small landholders. This is because land clearing using fire is the cost-effective way to create agricultural land that produces crops for them to survive. Therefore, the approach to mitigate forest fires should be different between small landholders and large landholders.

The involvement of people living in rural areas might be an alternative way to forest fire mitigation and biodiversity protection in Indonesia's tropical forests. As social conflicts mainly cause forest fires, Community Based Forest Management (CBFM) offers greater access to the forest resources and preserving them sustainably. In addition, the rural people have a significant interest in the forests because the tropical forests provide important resources for supporting their livelihood; therefore, they have to ensure the forest resources sustainability [32]. As a result, forest biodiversity can be preserved by the local people and improve their livelihood. In addition, there are several main reasons why local people need to be involved in forest management; escalating concern about deforestation, social pressures, and call for a greater role of governance from local people and significant spending in the operational cost of forest management by the government [33]. The author also suggests that meeting the importance of forest conservation and demand for food, fuel, and profit is a challenge in the forestry sector.

In Indonesia, Community Based Forest Management (CBFM) might play a significant role in achieving sustainable forest management, including forest fire prevention and biodiversity protection. In Lampung, a Sumatra province, the local community's involvement in managing the forests have significantly reduced forest fire hazard, rehabilitated degraded land, improved the local environment, and generated household income by applying coffee-based agroforestry [15]. This indicates that the application of CBFM in forest management can 
indirectly mitigate forest fire and preserving forest biodiversity. The local communities increase resilience to forest fire hazards by securing and preventing the forest from fire hazards because forest resources are an important income source.

The rural people who participate in CBFM can also assist in securing forest resources from fire. As the forests are located near to their village, the fire can directly affect their residence. A study conducted by [34] shows that villagers in several districts in Sumatra and Kalimantan establish a special organization to prevent and control forest fires in forest areas near their villages. In this study, the establishment of fire prevention organizations is supported by the government or Non-Government Organization (NGO) by providing fire extinguisher tools and fire mitigation education. As a consequence, the forest fire incidence can be reduced and mitigated.

\subsection{Challenges of CBFM Implementation}

Implementing CBFM as a mitigation action on a forest fire is necessary to tackle its challenges to prevent forest biodiversity loss. One of the main challenges in implementing CBFM in Indonesia is the land tenure issue. Data from [35] reveals that from a total of 129 million hectares of forest areas in this country, only about 11 million hectares of forest areas have clear boundaries. This indicates that the large proportion of forest areas in Indonesia is susceptible to the social conflicts related to land ownership between local government, central government, and sometimes, traditional communities that have lived for many years. On the other hand, determining the forest boundaries conducted by the ministry of forestry is influenced by the limited number of forestry officials.

Another challenge in the application of CBFM in Indonesia is the inefficient time in the application process. This is mainly caused by overlapping authority between central and local government [36], which is related to a quick change of governance from centralistic to de-centralistic after economic crises in 1998. This results in a conflict of interest between the local and central government in managing the forest resource [37].

Another issue that results in a slow process in applying CBFM is that many hierarchical institutions from the other ministerial agencies are involved in the permits' approval. As the application process involves several levels of institutions from the local village to the provincial government under the ministry of internal affairs [38], it takes a noticeable time to verify and accept the application of CBFM. Furthermore, in Kalimantan and Sumatra, there is a significant distance between the village governmental office and provincial office. In addition, internet communication is unpopular in villages that are located in remote areas. There are 20 institutions involved in 'Hutan Tanaman Rakyat' (Small Holder Forest Plantations), one of the CBFM programs managed by the local, mainly from the Ministry of Forestry, Ministry of Internal Affairs, Ministry of Finance, as the investment provider, and nongovernmental organization people [39].

\subsection{How to Improve CBFM in Indonesia}

The attempts to improve the CBFM programs in Indonesia can be focussed on two main actors; participants and governments. For the participants, the government's provision of field assistants might be important to deliver detailed information about the programs. Most forest farmers with low education might not fully understand how to be involved in the program. The field assistants can assist in applying for CBFM permit, species selection, nursery establishment and maintenance, plant and maintain trees, supervising the projects, and writing progress reports of the program. Assistant provision is an important element in supporting the CBFM programs in Indonesia [39].

For the government to improve CBFM in Indonesia, it might be necessary to establish a special agency or task force, which has specific duties on improving CBFM programs. This agency needs to have members representing each related ministrial institution to provide an effective and efficient CBFM application programs process. This agency can be analogous to the 'one-stop services' agency created by several local governments to promote investments. For example, a one-stop service policy, which has been implemented by one of the local governments in the Semarang regency, has a positive impact on the service quality indicated by increasing economic capital investment [40].

In addition, to solve the land tenure issue, the government needs to provide a clear boundary on forest areas. To achieve this, it needs effective communication among relevant stakeholders such as; local government, private and public landholders. To facilitate communication between stakeholders, the government might create a special task force that consists of members representing these relevant stakeholders. Meanwhile, the forestry ministry needs to recruit new personnel to increase the number of forestry officials to establish a clear boundary of the forest areas. For instance, the Ministry of Forestry has introduced BASARHUT (Bakti Sarjana Kehutanan or Bachelor Internship Program). Some fresh-graduate students from forest-related studies are invited to actively run a government program called 'forest management unit entity' [41]. Currently, about 120 students are contributing to this program. Thus, the government might apply this method as well. With capacity building on theoretical in forestry, these fresh-graduate students might provide significant assistance to tackle the 
problem and provide experience in the real world for them.

\section{CONCLUSIONS}

In conclusion, climate change has indirect negative impacts on forest biodiversity in Indonesia. In an extreme drought due to El Nino, forest fires result in significant loss of forest biodiversity. However, forest fires are a complex problem in Indonesia because social problems are also an influential factor that aggravates the forest fires. Therefore, to combat forest fires, several adaptation and mitigation measures need to be conducted. Forest fire adaptation strategies are to reformulate existing policies and regulations to provide an immediate response to climate change and forest fires.

In contrast, mitigation strategies are intended to prevent fire. Meanwhile, CBFM is one of the potential mitigation options to tackle forest fires in Indonesia because it allows the local people to access and maintain forest resources, including preventing forest fires. The CBFM can also reduce the social conflicts between local people, but the implementation of CBFM in this country needs to be improved.

\section{REFERENCES}

[1] N.S. Sodhi, L.P. Koh, B.W. Brook, P.K. Ng, Southeast Asian Biodiversity: An Impending Disaster, Trends in Ecology and Evolution, 19, 2004, pp. 654-660.

[2] R.A. Mittermeier, N. Myers, C.G. Mittermeier, P.R. Gil, Hotspots: Earth's Biologically Richest and Most Endangered Terrestrial Ecoregions, Cemex, Sa, Agrupación Sierra Madre, Sc, 1999.

[3] P.A. Colinvaux, P. de Oliveira, M. Bush, Amazonian and Neotropical Plant Communities on Glacial Time-Scales: The Failure of the Aridity and Refuge Hypotheses, Quaternary Science Reviews, 19, 2000, pp. 141-169.

[4] S.J. Wright, Tropical Forests in a Changing Environment, Trends In Ecology \& Evolution, 20, 2005, pp. 553-560.

[5] R.T. Corlett, J.V. Lafrankie Jr, Potential Impacts of Climate Change on Tropical Asian Forests Through an Influence on Phenology, Potential Impacts of Climate Change on Tropical Forest Ecosystems, Springer, 1998.

[6] F. Siegert, G. Ruecker, A. Hinrichs, A.A. Hoffmann, Increased Damage from Fires in Logged Forests during Droughts Caused by El Nino, Nature, 414, 2001, p. 437.

[7] A.A. Hoffmann, A. Hinrichs, F. Siegert, Fire Damage in East Kalimantan in 1997/98 Related to
Land Use and Vegetation Classes: Satellite Radar Inventory Results and Proposal for Further Actions. IFFM-SFMO Report, 1999.

[8] J.G. Goldammer, History of Equatorial Vegetation Fires and Fire Research in Southeast Asia Before the 1997-98, Episode: A Reconstruction of Creeping Environmental Changes. Mitigation And Adaptation Strategies for Global Change, 12, 2007, pp. 13-32.

[9] M. Collins, S.-I. An, W. Cai, A. Ganachaud, E. Guilyardi, F.-F. Jin, M. Jochum, M. Lengaigne, S. Power, A. Timmermann, The Impact of Global Warming on the Tropical Pacific Ocean and El Niño, Nature Geoscience, 3, 2010, pp. 391-397.

[10] M.E. Marlier, R.S. Defries, P.S. Kim, S.N. Koplitz, D.J. Jacob, L.J. Mickley, S.S. Myers, Fire Emissions and Regional Air Quality Impacts from Fires in Oil Palm, Timber, and Logging Concessions in Indonesia. Environmental Research Letters, 10, 085005, 2015.

[11] S. Suyanto, N. Khususiyah, Kemiskinan Masyarakat dan Ketergantungan pada Sumberdaya Alam: Sebuah Akar Penyebab Kebakaran di Sumatera Selatan, N. 2004.

[12] L. Tacconi, Fires in Indonesia: Causes, Costs, and Policy Implications. CIFOR, Bogor, Indonesia, 2003.

[13] R.A. Dennis, J. Mayer, G. Applegate, U. Chokkalingam, C.J. Colfer, I. Kurniawan, H. Lachowski, P. Maus, R.P. Permana, Y. Ruchiat, Fire, People and Pixels: Linking Social Science and Remote Sensing to Understand Underlying Causes and Impacts of Fires In Indonesia, Human Ecology, 33, 2005, pp. 465-504.

[14] D. Simorangkir, Fire Use: Is it really the Cheaper Land Preparation Method for Large-Scale Plantations? Mitigation And Adaptation Strategies For Global Change, 12, 2007, pp. 147-164.

[15] S. Suyanto, R.P. Permana, N. Khususiyah, L. Joshi, Land Tenure, Agroforestry Adoption, and Reduction of Fire Hazard in a Forest Zone: A Case Study from Lampung, Sumatra, Indonesia. Agroforestry Systems, 65, 2005, pp. 1-11.

[16] J.F. Slik, R.W. Verburg, P.J. Kessler, Effects of Fire and Selective Logging on the Tree Species Composition of Lowland Dipterocarp Forest in East Kalimantan, Indonesia. Biodiversity \& Conservation, 11, 2002, pp. 85-98.

[17] K. Sidiyasa, Struktur dan Komposisi Tegakan Serta Keanekaragamannya di Hutan Lindung Sungai Wain, Balikpapan, Kalimantan Timur, Jurnal 
Penelitian Hutan dan Konservasi Alam, 4, 2009, pp. 79-90.

[18] D.C. Nepstad, A. Verssimo, A. Alencar, C. Nobre, E. Lima, P. Lefebvre, P. Schlesinger, C. Potter, P. Moutinho, E. Mendoza, Large-Scale Impoverishment of Amazonian Forests by Logging and Fire. Nature, 398, 1999, pp. 505-508.

[19] M. Siscawati, Underlying Causes of Deforestation and Forest Degradation in Indonesia: A Case Study on Forest Fire, Proceedings of the International Workshop on Forest Conservation Strategies for the Asia and Pacific Region, Institute for Global Environmental Strategies, Kanagawa, 1999, pp. 4457.

[20] G. Fredriksson, Extinguishing the 1998 Forest Fires and Subsequent Coal Fires in the Sungai Wain Protection Forest, East Kalimantan, Indonesia: Communities in Flames, Proceedings of an International Conference on Community Involvement in Fire Management, FAO and Firefight SE Asia, 1999, pp. 74-81.

[21] M.G. Van Nieuwstadt, D. Sheil, K. Kartawinata, The Ecological Consequences of Logging in the Burned Forests of East Kalimantan, Indonesia, Conservation Biology, 15, 2001, pp. 1183-1186.

[22] G.R. Van Der Werf, J. Dempewolf, S.N. Trigg, J.T. Randerson, P.S. Kasibhatla, L. Giglio, D. Murdiyarso, W. Peters, D. Morton, G. Collatz, Climate Regulation of Fire Emissions and Deforestation in Equatorial Asia. Proceedings of The National Academy Of Sciences, 105, 2008, pp. 20350-20355.

[23] H. Herawati, H. Santoso, Tropical Forest Susceptibility To and Risk of Fire under Changing Climate: A Review of Fire Nature, Policy and Institutions in Indonesia. Forest Policy And Economics, 13, 2011, pp. 227-233.

[24] Directorate of Forest Fire Control. Profil: Manggala Agni [Online]. Ministry of Forestry, Jakarta, Indonesia, Available: Http://Www.Dephut.Go.Id/Neosis/Indofire/Index.P hp/Manggala_Agni [Accessed 23 October 2015].

[25] M.E. Harrison, S.E. Page, S.H. Limin, The Global Impact of Indonesian Forest Fires, Biologist, 56, 2009, pp. 156-163.

[26] E. Meijaard, Erik Meijaard: Indonesia's Fire Crisis - The Biggest Environmental Crime of the 21st Century. The Jakarta Globe, 23 October 2015.

[27] H. Boehm, F. Siegert, Ecological Impact of the One Million Hectare Rice Project in Central Kalimantan, Indonesia, Using Remote Sensing and
GIS., Paper Presented at the 22nd Asian Conference On Remote Sensing 2001, 2002, p. 9.

[28] S.E. Page, F. Siegert, J.O. Rieley, H.-D.V. Boehm, A.S. Jaya, The Amount of Carbon Released from Peat and Forest Fires in Indonesia during 1997. Nature, 420, 2002, p. 61.

[29] Ministry of Forestry, Peraturan Menteri Kehutanan Tentang Tata Cara Permohonan Ijin Usaha Pemanfaatan Hasil Hutan Kayu pada Hutan Tanaman Rakyat, Ministry of Forestry, Jakarta, 2013.

[30] B.P. Resosudarmo, Implementing a National Environmental Policy: Understanding the 'Success' of the 1989-1999 Integrated Pest Management Programme in Indonesia. Singapore Journal of Tropical Geography, 33, 2012, pp. 365380.

[31] C. Thorburn, Empire Strikes Back: The Making and Unmaking of Indonesia's National Integrated Pest Management Program. Agroecology and Sustainable Food Systems, 38, 2013, pp. 3-24.

[32] D. Macqueen, P. Demarsh, G.S. Pandey, E.C. Diaz, L. Robinson, S. Lewis, Investing in Locally Controlled Forestry: Natural Protection for People and Planet, iied, London, 2012.

[33] A. Agrawal, A. Chhatre, R. Hardin, Changing Governance of the World's Forests. Science, 320, 2008, pp. 1460-1462.

[34] A. Akbar, Pengendalian Kebakaran Hutan Berbasis Masyarakat Sebagai Statu Upaya Mengatasi Resiko dalam REDD, Tekno Hutan Tanaman, 1, 2007, pp. 11-22.

[35] Ministry of Forestry Indonesia, Ministry of Forestry Statistics 2013, in: Ministry of Forestry (Ed.). Bureau of Planning, Ministry of Forestry Indonesia, Jakarta, 2014

[36] Y. Kusumanto, M.T. Sirait, Community Participation in Forest Resource Management in Indonesia: Policies, Practices, Constraints and Opportunities, Southeast Asia Policy Research Working Paper, 28, 2002, pp. 1-28.

[37] M. Baiquni, R. Rijanta, Konflik Pengelolaan Lingkungan dan Sumberdaya dalam Era Otonomi dan Transisi Masyarakat, Bumi Lestari, 7, 2007, p. $1-3$.

[38] Ministry Of State Secretary, Produk PerundangUndangan Indonesia [Online], Ministry Of State Secretary, Jakarta, 2013. Available: Http://www.Setneg.Go.Id/Index.Php?Option=Com Perundangan $\& I d=2344 \&$ Task $=$ Detail $\&$ Catid $=1 \&$ 
$\underline{\text { Itemid }=42 \& \text { Tahun=2009 }}$ [Accessed 20 October 2015].

[39] T. Herawati, Hutan Tanaman Rakyat: Analisis Proses Perumusan Kebijakan Dan Rancang Bangun Model Konseptual Kebijakan, Doctoral, Bogor Agricultural Institute, 2011.

[40] J.S. Setyono, M. Muktiali, Analisis Pengembangan Pelayanan Terpadu Satu Pintu Sesuai dengan Karakteristik Perkembangan Kota Semarang, Jurnal Riptek, 3, 2009, pp. 13-23.

[41] Ministry of Forestry, Basarhut Menjadi Upaya Terobosan untuk Memenuhi Kebutuhan Minimal Sdm Pengelola KPH [Online]. Jakarta, Indonesia: Bp2sdmk Ministry of Forestry, 2014. Available: Http://Bp2sdmk.Dephut.Go.Id/Index.Php/Berita1/2 02-Basarhut-Menjadi-Upaya-Terobosan-UntukMemenuhi-Kebutuhan-Minimal-Sdm-Pengelola$\underline{\text { Kph }}$ [Accessed 4 September 2015]. 